\title{
PENGARUH PENGGUNAAN MEDIA VIRTUAL REALITY TERHADAP HASIL BELAJAR ANAK KELOMPOK B PADA TEMA PENGENALAN BINATANG BUAS
}

\author{
I Made Sukaryawan'), Nyoman Sugihartini'2), \\ I Made Ardwi Pradnyana3). \\ 1,2,3Fakultas Teknik dan Kejuruan, Universitas Pendidikan Singaraja \\ Email: Shukok84@gmail.com¹ ${ }^{\text {, sugihartini@undiksha.ac.id² }}$, ardwi.pradnyana@undiksha.ac.id $^{3}$
}

\begin{abstract}
ABSTRAK
Pengaruh media Virtual Reality terhadap hasil belajar anak kelompok B pada tema pengenalan binatang buas Adapun tujuan dari penelitian ini yaitu : (1) untuk mengetahui pengaruh penggunaan media Virtual Reallity terhadap rata-rata hasil belajar anak kelompok B pada tema pengenalan binatang buas diTK wangun sesana, (2) untuk mengetahui respon anak usia dini diTK Wangun Sesana Singaraja setelah menggunakan media Virtual Reality pengenalan binatang buas. Jenis penelitian yang digunakan yaitu eksperimen semu (quasi experiment) dengan menggunakan model pembelajaran klasikal, sampel penelitian yang digunakan adalah anak kelompok B di TK Wangun Sesana tahun ajaran 2018/2019. Hasil penelitian menunjukan bahwa (1) terdapat perbedaan pada hasil belajar anak yang menggunakan media virtual reality dengan siswa yang menggunakan media kartu bergambar diTK Wangun Sesana dengan rata-rata hasil belajar kelompok eksperimen adalah 9,50 dan untuk rata-rata hasil belajar untuk kelas control yaitu sebesar 6,74. Dengan demikian dapat dinyatakan bahwa rata-rata post test hasil belajar pada kelompok eksperimen lebih besar dibandingkan kelompok kontrol (2) Hasil dari analisis respon siswa dari penerapan media Virtual Reality pada tema Pengenalan Binatang Buas dilihat dari rata - rata skor respon siswa sebesar 4,54 adalah termasuk dalam kategori sangat positif
\end{abstract}

Kata kunci: Virtual Reality, Model Klasikal, Hasil Belajar.

\begin{abstract}
The influence of Virtual Reality media on the learning outcomes of group $B$ children on the theme of wild animal recognition The objectives of this study are: (1) to determine the effect of using Virtual Reality media on the average learning outcomes of group B children on the theme of introducing wild animals at a time, (2) to find out the response of early childhood in TK Wangun Sesana Singaraja after using Virtual Reality media for the introduction of wild animals. The type of research used is a quasi-experiment using the classical learning model, the study sample used was group B children at the Wangun Sesana Kindergarten in the 2018/2019 school year. The results showed that (1) there were differences in the learning outcomes of children using Virtual reality media with students who use pictorial card media in TK Wangun Sesana with the average learning outcomes of the experimental group is 9.50 and for the average learning outcomes for the control class is 6.74. Thus it can be stated that the average post-test of learning outcomes in the experimental group is greater than the control group (2) The results of analysis of student responses from the application of Virtual Reality media on the theme of Introduction to Wild Beasts are seen from the average student response score of 4.54 is included in the very positive category
\end{abstract}

Keywords : Virtual Reality, Classical Model, Learning Outcomes. 


\section{PENDAHULUAN}

Anak usia dini merupakan pendidikan jalur formal diusia 4-6 tahun. Pendidikan TK memiliki peran yang sangat penting untuk pengembangan kepribadian anak, serta untuk mempersiapkan mereka untuk memasuki jenjang pendidikan selanjutnya. Standar kompetensi TK yang tercantum dalam tujuan pendidikan di Taman Kanak-kanak adalah membantu mengembangkan berbagai potensi anak, baik psikis dan fisik yang meliputi moral dan nilai agama, sosial, emosional, kognitif, Bahasa, seni, dan fisik motorik. [1], Dalam Undang-undang Nomor 20 Tahun 2003 tentang Sistem Pendidikan Nasional, pada Pasal 1 butir 14 pendidikan anak usia dini (PAUD) diartikan sebagai: Suatu upaya pembinaan yang ditujukan kepada anak sejak lahir sampai dengan usia enam tahun yang dilakukan melalui pemberian rangsangan pendidikan untuk membantu pertumbuhan dan perkembangan jasmani dan rohani agar anak memiliki kesiapan dalam memasuki pendidikan lebih lanjut. Pendidikan TK memiliki peran yang sangat penting untuk pengembangan kepribadian anak, serta untuk mempersiapkan mereka untuk memasuki jenjang pendidikan selanjutnya. Standar kompetensi TK yang tercantum dalam tujuan pendidikan di Taman Kanak-kanak adalah membantu mengembangkan berbagai potensi anak, baik psikis dan fisik yang meliputi moral dan nilai agama, sosial, emosional, kognitif, Bahasa, seni, dan fisik motorik.

Berbagai potensi itu dikembangkan melalui kegiatan yang beraneka ragam dan dijadikan sebagai bahan pembelajaran di Taman Kanak-kanak. Kegiatan pembelajaran di TK pada umumnya dikemas agar anak tertarik, sehingga tanpa adanya kekangan anak dapat mengembangkan potensi yang dimiliki. Salah satu upaya yang dilakukan guru untuk membuat anak tertarik adalah dengan menggunakan media pembelajaran, karena Media berperan penting terhadap proses belajar mengajar, media pembelajaran ikut serta dalam membuat siswa menjadi lebih terobsesi ketika belajar. Pembelajaran di TK terdapat berbagai macam tema, salah satu tema yang diajarkan yaitu tentang pengenalan binatang. Media yang bisa digunakan dalam penelitian ini yaitu media pembelajaran yang berbasis Virtual Reality.

. VR atau realitas maya adalah teknologi yang dibuat sehingga pengguna dapat berinteraksi dengan suatu lingkungan yang disimulasikan oleh komputer (computer-simulated environment). Lingkungan yang ditirukan dapat menjadi mirip dengan dunia nyata, pengalaman realitas maya yang representatif dengan mengikutsertakan simulasi kombinasi hasil penginderaan (visual, audio, peraba) [2]. teknologi virtual reality juga mulai dikembangkan dalam dunia pendidikan, teknologi jenis ini menjadi terobosan baru dalam kegiatan belajar mengajar, karena teknologi ini dapat meningkatkan imajinasi yang dimiliki siswa untuk merancang dan menggambarkannya ke dalam bentuk nyata. Dengan begitu kegiatan belajar mengajar akan semakin menarik dan terjadi proses interaksi.

Dalam menggunakan media pembelajaran yang inovatif hendaknya juga menggunakan model pembelajaran yang tepat sehingga mempermudah proses penggunaan media pembelajaran. Model pembelajaran yang digunakan untuk menunjang penggunaan media pembelajaran yaitu dengan model pembelajaran klasikal. Model Pembelajaran Klasikal dapat diartikan sebagai pembelajaran dimana dalam waktu yang sama, kegiatan dilakukan oleh seluruh anak sama dalam satu kelas (secara klasikal). Model pembelajaran ini merupakan model yang paling awal digunakan di PAUD. Dengan sarana atau media pembelajaran yang terbatas, Dimana anak bisa lebih aktif dan kreatif dalam menuangkan gagasan atau ide-idenya tersebut. Selain itu, model pembelajaran klasikal banyak digunakan pada pembelajaran anak usia dini karena dapat melatih kemampuan kerjasama, perkembangan sosial anak, dapat melatih rasa tanggung jawab terhadap pekerjaan yang menjadi tugasnya, membangun kemampuan berinteraksi, berbagi ide, pendapat, mampu mengendalikan emosi, bersedia memberi dan menerima.

Hasil wawancara yang dilakukan peneliti dengan menyebar angket terhadap guru di TK Wangun Sesana Singaraja atas nama Ibu Komang Apriliani mengenai penggunaan media dimana guru masih menggunakan media cetak, seperti menggunakan media gambar pada saat menjelaskan materi pengenalan binatang buas. Sehingga peneliti memberikan solusi untuk menggunakan media Virtual Reality untuk dijadikan media untuk pendukung proses pembelajaran yang dimana diharapkan mampu membantu siswa untuk membuat siswa lebih aktif pada saat pembelajaran berlangsung dan mampu meraih hasil belajar yang maksimal.

Penelitian terkait sebelumnya yang berjudul pengembangan virtual reality pengenalan binatang buas untuk anak usia dini, Penyampaian materi pembelajaran dengan tema binatang khususnya binatang buas kepada anak usia dini menjadi tantangan tersendiri bagi guru. Media pembejalaran dua dimensi berupa gambar yang monoton berpotensi menurunkan minat belajar anak, Berdasarkan permasalahan tersebut, maka dibuatlah aplikasi berbasis android yang memuat empat belas jenis binatang buas dalam format 3D yang dikemas dengan teknologi Virtual Reality (VR). Hasil penelitian 
ini Rata-rata persentase untuk uji respon pengguna adalah $88.50 \%$, yang artinya sangat baik dimana anak-anak dapat mengetahui jenis-jenis binatang buas, gerak binatang buas, suara dari binatang buas, habitat binatang buas serta dapat menggunakan aplikasi dengan mudah [3].

Berdasarkan uraian latar belakang dapat dirumuskan permasalahan untuk dicari solusinya adalah sebagai berikut: (1) bagaimana pengaruh penggunaan media Virtual Reality terhadap hasil belajar anak pada tema pengenalan binatang buas di TK Wangun Sesana Singaraja? (2) bagaimana respon anak mengenai pembelajaran dengan menggunakan media Virtual Reality pada tema pengenalan binatang buas di TK Wangun Sesana Singaraja?

Berdasarkan rumusan masalah yang diuraikan diatas, tujuan penelitian ini adalah: (1) Untuk mengetahui pengaruh penggunaan media Virtual Reality terhadap hasil belajar anak pada tema pengenalan binatang buas di TK Wangun Sesana Singaraja. (2) Untuk mengetahui respon anak mengenai pembelajaran menggunakan media Virtual Reality pada tema pengenalan binatang buas di TK Wangun Sesana Singaraja.

Terkait dengan hal ini maka timbul minat peneliti untuk mengkaji lebih jauh apakah penerapan Media Pembelajaran berbasis VR ( Virtual Reality) diterapkan di TK Wangun Sesana Singaraja dengan tujuan ingin mengetahui seberapa besar hasil belajar di TK tersebut saat menggunakan Media Virtual Reality pada tema pengenalan binatang buas dalam proses pembelajaran berlangsung. Penelitian Eksperimen ini memiliki tujuan untuk mengetahui perbedaan pengaruh penerapan media pembelajaran Virtual Reality dan pembelajaran tanpa menggunakan media pembelajaran Virtual Reality terhadap hasil belajar anak di TK Wangun Sesana Singaraja.

\section{Media Pembelajaran}

Media pembelajaran ini sangat membantu pendidik dalam melakukan proses belajar mengajar dimana media pembelajaran berfungsi untuk mencuri perhatian siswa agar para siswa tertuju kepada materi yang disampaikan oleh pengajar atau pendidik. Media pembelajaran berupa bahan, alat, atau teknik yang digunakan dalam kegiatan belajar mengajar dengan maksud agar proses interaksi komunikasi edukasi antara guru dan siswa dapat berlangsung secara tepat guna dan berdaya guna. Media pembelajaran adalah segala sesuatu yang digunakan untuk menyalurkan pesan serta dapat merangsang pikiran, perasaan, perhatian, dan kemauan si belajar sehingga dapat mendorong terjadinya proses belajar. [5]

\section{Media Virtual Reality Pengenalan Binatang Buas}

Pengembangan virtual reality pengenalan binatang buas untuk anak usia dini,[3] Tujuan media ini yaitu untuk membantu proses pembelajaran di TK (Taman Kanak Kanak) dengan tema pengenalan binatang buas. Pengembangan media ini ditujukan kepada anak-anak TK (Taman Kanak Kanak) agar dapat menarik minat belajar serta mampu menambah wawasan tentang jenis-jenis binatang buas. Media ini membahas tentang pengenalan binatang buas dapat dipasang pada smartphone android.

\section{Materi Pengenalan Binatang Buas}

Pengenalan Binatang Buas menjadi salah satu tema yang diterapkan pada kurikulum pembelajaran di Taman Kanak-Kanak. Dalam pembelajaran dengan tema pengenalan binatang ada beberapa tahapan yang dilakukan oleh guru, seperti pengenalan atau memberi penjelasan mengenai apa itu binatang buas, mengelompokan binatang buas berdasarkan tempat hidupnya, tempat tinggalnya dan berdasarkan ciri-cirinya, memperlihatkan gambar binatang buas agar siswa tau bentuk dan rupa binatang yang disebutkan, Seperti: Singa, Harimau, Badak, Buaya, Gajah, Komodo, Beruang dan lain sebagainya. Dalam pembelajaran dengan tema Binatang guru menggunakan beberapa media antara lain media gambar dan media video, guru mencari media yang sesuai di internet agar kegiatan belajar mengajar berjalan dengan lancer

\section{Model Pembelajaran Klasikal}

Model pembelajaran klasikal adalah pola pembelajaran yang dilakukan pendidik (guru) bersama sekelompok peserta didik/murid dalam satu kelas secara bersamaan dengan aktivitas dan waktu yang sama pula. Model pembelajaran jenis ini biasanya diterapkan karena kurangnya atau minimnya ketersediaan sarana dan prasarana. Dengan demikian model pembelajaran klasikal dapat diartikan sebagai pembelajaran dimana dalam waktu yang sama dalam satu kelas (secara klasikal) [4]. Pelaksanaan pembelajaran dilakukan melalui pembelajaran langsung dan tidak langsung yang terjadi secara terintegrasi dan tidak terpisah. Pembelajaran langsung adalah proses pembelajaran melaui integrasi langsung antara anak dengan sumber belajar yang dirancang dalam rencana 
pelaksanaan pembelajaran harian (RPPH). Pembelajaran klasikal dilaksanakan dalam tahapan kegiatan pembukaan, inti, istirahat dan penutup.

\section{Kerangka Berpikir}

Pembelajaran dapat dikatakan berkualitas dan efektif apabila hasil belajar anak dapat meningkat dengan baik. Salah satu cara untuk meningkatkan hasil belajar anak yaitu dengan menerapakan pembelajaran menggunakan media pembelajaran yang menarik pada saat proses pembelajaran. Untuk menjawab masalah tersebut maka diberikan suatu media pembelajaran yang dapat diterapkan yaitu suatu media Virtual Reality dimana tujuannya membantu proses pembelajaran di TK (Taman Kanak Kanak) khususnya pada tema pengenalan Binatang Buas. Penggunaan media Virtual Reality merupakan faktor eksternal yang dapat berpengaruh terhadap hasil belajar. Media Virtual Reality ditujukan kepada anak-anak TK (Taman Kanak Kanak) agar dapat menarik minat belajar serta mampu menambah wawasan. Hasil pengujian dari pengembangan Virtual Reality pengenalan binatang buas untuk anak usia dini menunjukkan bahwa aplikasi mendapat respon yang positif dari pengguna khususnya anak-anak di TK Wangun Sesana Singaraja. Rata-rata persentase untuk uji respon pengguna adalah $88.50 \%$, yang artinya sangat baik dimana anak-anak dapat mengetahui jenis-jenis binatang buas, gerak binatang buas, suara dari binatang buas, habitat binatang buas serta dapat menggunakan aplikasi dengan mudah. Penggunaan media Virtual Reality khususnya pada anak usia dini juga menjadi salah satu faktor yang berpengaruh karena media pembelajaran bertujuan untuk mewujudkan dan merangsang motivasi belajar siswa sehingga siswa terdorong untuk belajar.

Berdasarkan hasil wawancara yang dilaksanakan di TK Wangun Sesana Singaraja pada kelompok B, bahwa media pembelajaran yang digunakan saat mengajar hanya sebatas ceramah dan menggunakan media cetak didalam pembelajaran pada tema pengenalan Binatang Buas. Dari uraian tersebut Media pembelajaran Virtual Reality diharapakan dapat menambah semangat belajar anak sehingga hasil belajar anak dapat meningkat dibandingkan dengan hasil pembelajaran sebelumnya.

\section{Hipotesis}

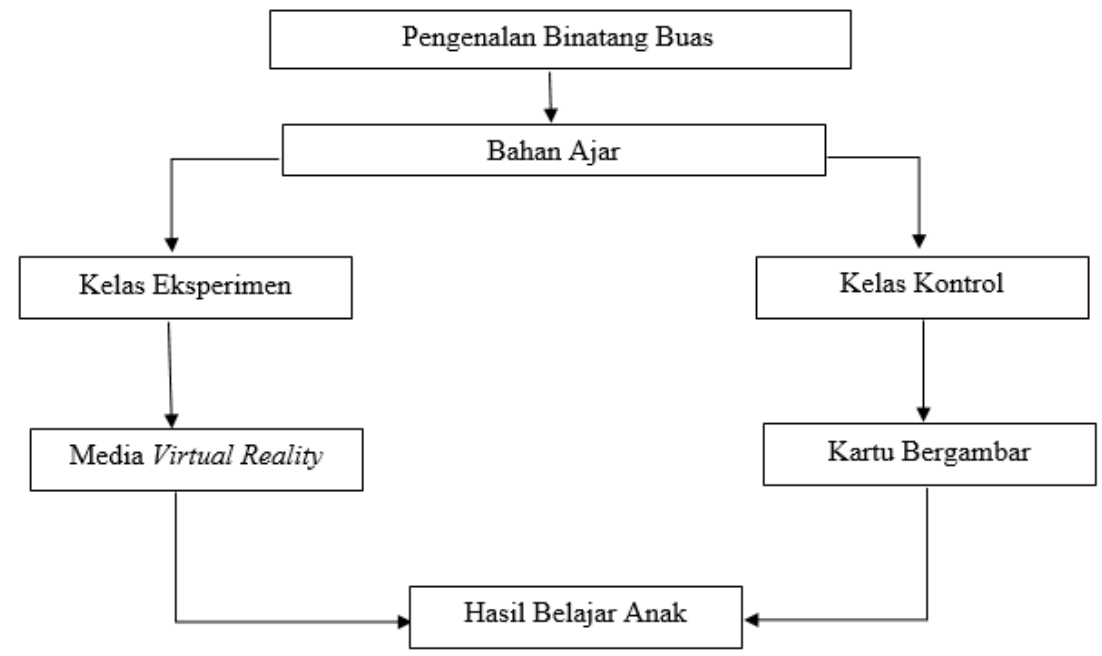

Gambar 1. Kerangka berpikir

Berdasarkan uraian dari kajian teori dan kerangka berpikir yang telah diungkapkan, maka dapat diru muskan hipotesis penelitian sebagai berikut "terdapat perbedaan kemampuan kognitif pada anak kelompok B yang dibelajarkan menggunakan media virtual reality dan anak kelompok B yang dibelajarkan menggunakan media pembelajaran cetak di TK Wangun Sesana Singaraja, maka hipotesis penelitian yang diajukan dirumuskan sebagai berikut: (1) Terdapat perbedaan hasil belajar antara anak yang belajar menggunakan media Virtual Reality dengan anak yang belajar menggunakan media cetak di TK Wangun Sesana Singaraja. (2) Terdapat respon yang positif dari siswa kelompok B di TK Wangun Sesana Singaraja dalam proses pembelajaran setelah menggunakan media virtual reality pada tema binatang buas.

\section{METODE}

\section{Jenis Penelitian}

Penelitian ini termasuk kategori penelitian eksperimen semu (quasi experiment). Peneliti menggunakan desain ini karena dalam penelitian ini terdapat variabel-varibel dari luar yang tidak dapat dikontrol oleh peneliti. Ciri utama dari quasi experimental design adalah pengembangan dari 
true experimental design, yang mempunyai kelompok kontrol namun tidak dapat berfungsi sepenuhnya untuk mengontrol variabel-variabel dari luar yang mempengaruhi pelaksanaan eksperimen [6]. Penelitian ini bermaksud untuk mengetahui pengaruh penggunaan media pembelajaran Virtual Reality dan pembelajaran tanpa menggunakan media pembelajaran Virtual Reality pada tema pengenalan binatang buas terhadap hasil belajar anak di TK Wangun Sesana Singaraja. Penelitian ini menggunakan 2 kelas yaitu kelas eksperimen dan kelas kontrol dimana kelas eksperimen menggunakan media pembelajaran Virtual Reality dan kelas control menerapkan pembelajaran tanpa menggunakan media pembelajaran Virtual Reality.

\section{Rancangan Penelitian}

Desain yang digunakan oleh peneliti adalah post-test only control group design. Desain penelitian ini dipilih karena peneliti hanya ingin mengukur hasil belajar siswa sesudah perlakuan dalam penelitian ini peneliti menggunakan dua kelompok, dimana pemilihan kelompok ini secara random atau acak. Dua kelompok ini akan dibagi, kelompok pertama akan diberi perlakuan dan kelompok yang lain tidak diberi perlakuan.

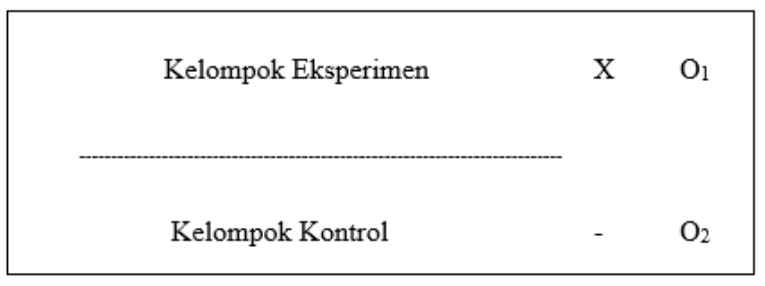

\section{Sampel Penelitian}

Gambar 2. Desain Rancangan Penelitian

Teknik pengambilan sampel yang digunakan dalam penelitian ini adalah simple random sampling. Cara pengambilan sampel ini dipilih karena sulit mengubah kelompok yang sudah terbentuk. Maka kelompok dipilih sebagaimana yang telah ada atau sudah terbentuk tanpa campur tangan peneliti sehingga kemungkinan pengaruh-pengaruh dari keadaan subjek mengetahui dirinya dilibatkan dalam eksperimen dapat dikurangi sehingga penelitian ini benar-benar dapat menggambarkan pengaruh perlakuan yang diberikan. Sebelum kelompok-kelompok ini dipakai maka dilakukan uji kesetaraan dimana dalam uji kesetaraan ini akan menentukan apakah kelompok yang akan dipakai setara karena dalam menentukan kelompok diperlukan dua kelompok yang nilai rataratanya saling mendekati maka dua kelompok itu diasumsikan setara dan dapat digunakan sebagai sampel penelitian, Untuk menunjukkan bahwa kedua kelompok tersebut setara, maka dapat juga dilakukan pengujian dengan menggunakan Uji-t. Uji-t untuk sampel yang tidak berkorelasi atau terpisah terdiri dari dua jenis rumus, yaitu separated varians dan polled varians

$$
\begin{aligned}
& \text { Rumus (separated varians) } \\
& \mathrm{t}=\frac{\overline{\mathrm{x}}_{1}-\overline{\mathrm{x}}_{2}}{\sqrt{\frac{s_{1}^{2}}{\mathrm{n}_{1}}+\frac{s_{2}^{2}}{n_{2}}}} \\
& \text { atau } \\
& \text { Rumus (polled varians) } \\
& \mathrm{t}=\frac{\overline{\mathrm{x}}_{1}-\overline{\mathrm{x}}_{2}}{\sqrt{\frac{\left(\mathrm{n}_{1}-1\right) \mathrm{s}_{1}^{2}+\left(\mathrm{n}_{2}-1\right) \mathrm{s}_{2}^{2}}{\mathrm{n}_{1}+\mathrm{n}_{1}-2}\left(\frac{1}{\mathrm{n}_{1}}+\frac{1}{\mathrm{n}_{2}}\right)}} \\
& \text { Keterangan : } \\
& \bar{X}_{1} \quad=\text { Nilai rata-rata skor kelompok } 1 \\
& \bar{X}_{2} \quad=\text { Nilai rata-rata skor kelompok } 2 \\
& \mathrm{n}_{1} \quad=\text { Banyaknya subjek kelompok } 1 \\
& \mathrm{n}_{2} \text { = Banyaknya subjek kelompok } 2 \\
& \mathrm{sl}^{2} \quad=\text { varians sampel kelompok } 1 \\
& \mathrm{~s}_{2}{ }^{2}=\text { varians sampel kelompok } 2
\end{aligned}
$$




\section{Variabel Penelitian}

Didalam penlitian ini menggunakan 2 variabel, yaitu yaitu variabel bebas dan variabel terikat, variabel bebas dalam penelitian ini adalah media Virtual Reality, variabel terikat pada penelitian ini yaitu hasil belajar pada kelompok B di TK Wangun Sesana.

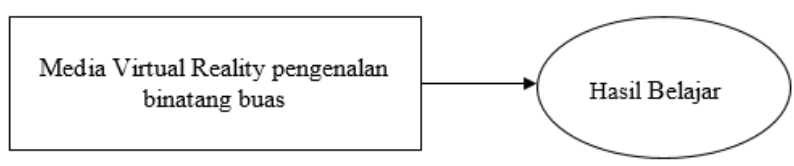

Gambar 3. Diagram Hubungan Variabel Penelitian

\section{Teknik Pengumpulan Data}

Teknik pengumpulan data, dimana peneliti mengunakannya sebagai sarana yang digunakan untuk mengambil data dan mendukung dalam suatu penelitian, peneliti menggunakan teknik pengumpulan data sebagai berikut yaitu: Observasi, Test dan Dokumentasi

\section{Istrumen Hasil Belajar}

Intrumen yang digunakan dalam penelitian ini adalah tes hasil belajar. Tes ini mengungkapkan tentang penguasaan anak terhadap pelajaran tema pengenalan binatang buas. Dari enam aspek ranah kognitif yang di kemukakan oleh Bloom, ranah kognitif yang di gunakan peneliti dalam pembuatan instrument soal uraian adalah pengetahuan (C1), pemahaman (C2). Pemilihan aspek C1 C2 ini berdasarkan hasil telaah indikator pada setiap kompetensi dasar yang digunakan. Kata operasional pada indikator materi yang diajarkan adalah "Pemahaman". Sehingga batas minimal aspek cukup hanya sampai aspek analisis.

\section{Instrumen Respon Siswa}

Pada instrument respon belajar siswa dalam penelitian ini menggunakan metode observasi, dimana lembar observasi yang digunakan menggunakan checklist. Lembar observasi akan menggunakan skala Likert dengan rentang skor minimal 1 sampai dengan maksimal 5 untuk setiap item soal.

\section{Uji Coba Instrumen}

Pada uji coba instrumen dilakukan uji prasyarat terhadap perangkat pembelajaran dan instrument penelitian dilakukan pengujian terlebih dahulu untuk mendapatkan gambaran secara empirik apakah perangkat dan instrument layak digunakan dalam penelitian. Instrument dikatakan sesuai jika instrument tersebut sudah memenuhi kriteria validasi, reliabilitas. Untuk memperoleh tujuan dari proses analisis, data terlebih dahulu dianalisis dengan menggunakan uji validitas tes dan reliabilitas tes.

\section{Uji Validitas}

Uji validitas digunakan untuk mengukur sah, atau valid tidaknya suatu kuesioner. Suatu kuesioner dikatakan valid jika pertanyaan pada kuesioner mampu untuk mengungkapkan sesuatu yang akan diukur oleh kuesioner tersebut. Suatu tes dapat dikatakan memiliki validitas yang tinggi jika tes tersebut menjalankan fungsi ukurnya, atau memberikan hasil ukur yang tepat dan akurat sesuai dengan maksud dikenakannya tes tersebut.

\section{Uji Reliabilitas}

Reliabilitas adalah alat untuk mengukur suatu kuesioner yang merupakan indikator dari peubah atau konstruk. Suatu kuesioner dikatakan reliabel atau handal jika jawaban seseorang terhadap pernyataan adalah konsisten atau stabil dari waktu ke waktu. Reliabilitas suatu test merujuk pada derajat stabilitas, konsistensi, daya prediksi, dan akurasi. Pengukuran yang memiliki reliabilitas yang tinggi adalah pengukuran yang dapat menghasilkan data yang reliabel [7].

\section{Teknik Analisis Data}

Setelah data yang diperlukan telah diperoleh dan terkumpul harus dianalisis terlebih dahulu agar dapat disusun penyajian hipotesisnya dan sebagai dasar dalam penarikan kesimpulan. Teknik analisis data adalah cara yang digunakan dalam menganalisis data untuk menguji hipotesis yang diajukan. Analisis data ini digunakan untuk menyederhanakan data ke dalam bentuk yang lebih mudah dibaca serta diinterpretasikan agar dapat menjawab hipotesis yang peneliti lakukan. Metode 
yang dilakukan dalam penelitian ini adalah dengan menggunakan analisis deskriptif dan analisis statistik. (1) Analisis deskriptif dilakukan untuk mengetahui tinggi rendahnya kualitas dari hasil belajar. Metode analisis deskriptif kuantitatif adalah suatu cara pengolahan data yang dilakukan dengan jalan menerapkan rumus - rumus statistik deskriptif berupa angka rata- rata (mean), median, modus dan menghitung standar deviasi. (2) Stastistik inferensial yaitu yang pertama uji prasyarat analisis seperti uji normalitas sebaran data, uji homogenitas yang kedua uji hipotesis.

\section{Teknik Analisis Deskriptif Respon Siswa}

Respon siswa terhadap penggunaan media Virtual Reality pengenalan Binatang buas dikumpulkan dengan menggunakan lembar observasi. Lembar Observasi yang digunakan adalah skala Likert dengan pilihan Sangat Baik (SB), Baik (B), Cukup (C), Kurang (K), dan Sangat Kurang (SK).

\section{HASIL DAN PEMBAHASAN}

\section{Deskripsi Data Hasil Penelitian}

. Data dalam penelitian ini adalah skor hasil belajar anak kelompok B sebagai akibat dari penerapan media Virtual Reality pada kelompok eksperimen dan Kartu bergambar pada kelompok control

\section{Deskripsi Data Hasil Post-test Siswa Kelompok Eksperimen}

Berdasarkan data pengukuran hasil belajar kognitif pada tema binatang dengan sub tema pengenalan binatang buas terhadap 24 anak kelompok eksperimen, diperoleh data distribusi frekuensi skor post-test, bahwa skor tertinggi adalah 12 dan skor terendah adalah 4 .

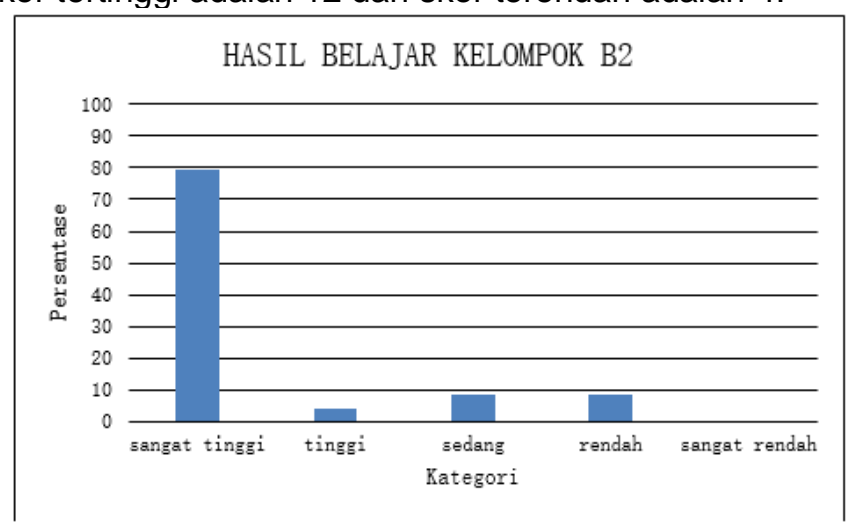

Gambar 4. Histogram Hasil Belajar Kelompok Eksperimen

Dapat diketahui bahwa hasil belajar kelompok eksperimen sebanyak $79,17 \%$ berkategori sangat tinggi, sebanyak $4.17 \%$ berkategori tinggi, sebanyak $8.33 \%$ berkategori sedang, sebanyak $8.33 \%$ berkategori rendah serta tidak ada siswa yang memiliki hasil belajar berkategori sangat rendah.

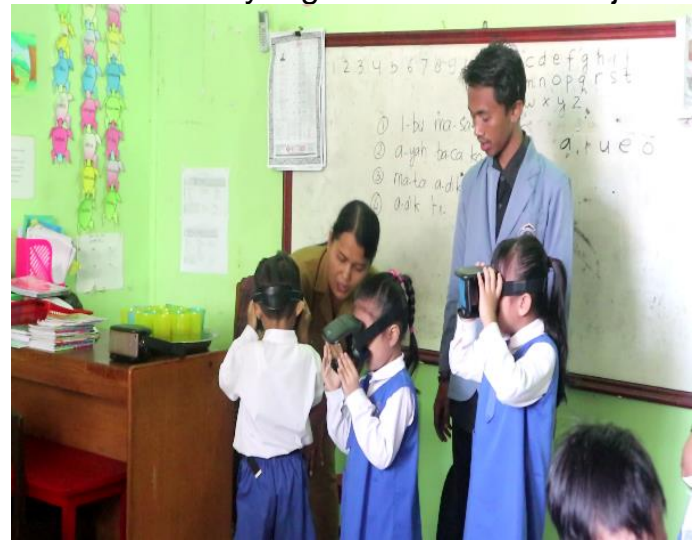

Gambar 5. Penggunaan media Virtual Reality 


\section{Deskripsi Data Hasil Post-test Siswa Kelompok Kontrol}

Berdasarkan data pengukuran hasil belajar kognitif tema Binatang,dengan sub tema pengenalan binatang buas terhadap 25 siswa kelompok kontrol, diketahui bahwa skor tertinggi siswa adalah 11 dan skor terendah siswa adalah 3.

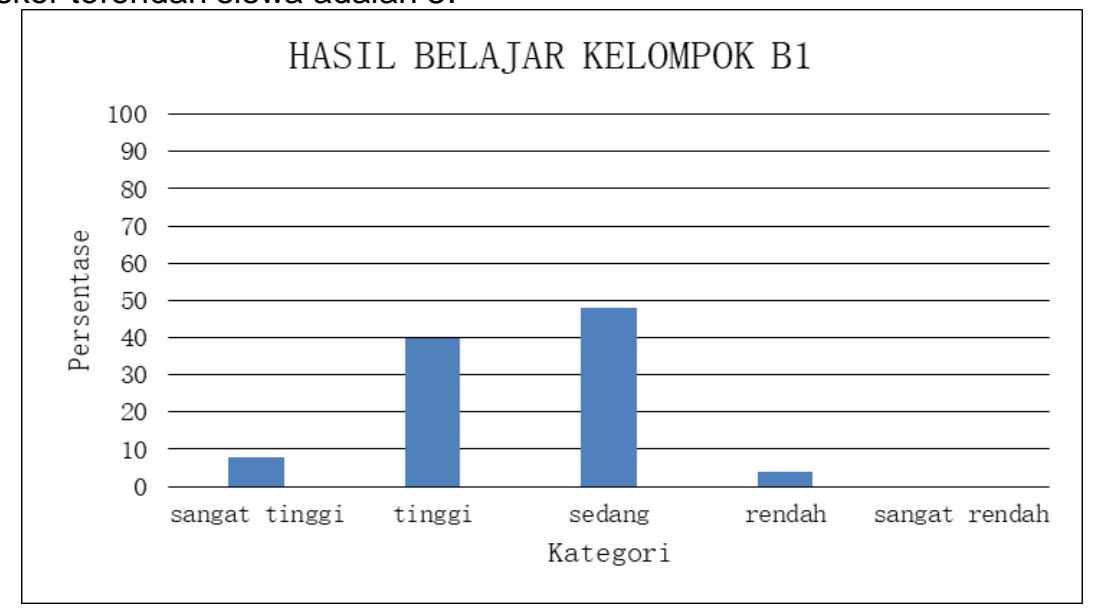

Gambar 6 Histogram Hasil Belajar Kelompok Kontrol

Dapat diketahui bahwa hasil belajar kelompok kontrol sebanyak $8,00 \%$ berkategori sangat tinggi, sebanyak $40,00 \%$ berkategori tinggi, sebanyak $48,00 \%$ berkategori sedang, sebanyak $4,00 \%$ berkategori rendah serta tidak ada anak yang memiliki hasil belajar sangat rendah.

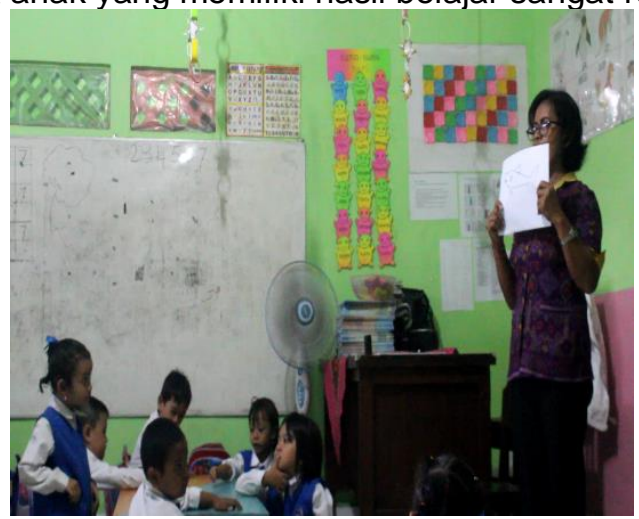

Gambar 7 penerapan menggunaan Media Kartu Bergambar

\section{Analisis Prasyarat Dan Pengujian Hipotesis}

Sebelum dilakukan pengujian hipotesis penelitian, maka terlebih dahulu dilakukan pengujian prasyarat analisis. Uji prasyarat analisis meliputi uji normalitas data yang dikenakan pada kedua kelompok dan uji homogenitas varians.

\section{Uji Normalitas Kelompok Eksperimen}

Data berdistribusi normal jika angka signifikasi yang diperoleh lebih besar daripada 0,05.

Tabel 1. Hasil Uji Normalitas Hasil Belajar Kelompok Eksperimen

\begin{tabular}{|c|c|c|c|c|c|c|c|}
\hline \multicolumn{2}{|c|}{ Kelas } & \multicolumn{3}{|c|}{ Kolmogorov-Smirnov } & \multicolumn{3}{c|}{ Shapiro-Wilk } \\
\hline \multirow{2}{*}{ Nilai } & Eksperimen & Statistic & df & Sig. & Statistic & df & Sig. \\
\cline { 3 - 8 } & & 0.209 & 24 & 0.08 & 0.895 & 24 & 0.17 \\
\hline
\end{tabular}

Berdasarkan hasil output analisis menunjukkan nilai Kolmogrov-Sminov dengan probabilitas (sig) sebesar 0,8 dan nilai Shapiro Wilk dengan probabilitas(a) sebesar 0,17 oleh karena nilai probabilitas kedua nilai signifikan $>0,05$ maka ini berarti bahwa data hasil posttest kelompok eksperimen berdistribusi normal yaitu tidak terdapat perbedaan frekuensi sebaran data kelompok eksperimen.

\section{Uji Normalitas Kelompok Kontrol}


Data berdistribusi normal jika angka signifikasi yang diperoleh lebih besar daripada 0,05,

Tabel 2. Hasil Uji Normalitas Hasil Belajar Kelompok Eksperimen

\begin{tabular}{|c|c|c|c|c|c|c|c|}
\hline \multicolumn{2}{|c|}{ Kelas } & \multicolumn{3}{|c|}{ Kolmogorov-Smirnov $\mathrm{a}^{\mathrm{a}}$} & \multicolumn{3}{c|}{ Shapiro-Wilk } \\
\hline \multirow{2}{*}{ Nilai } & \multirow{2}{*}{ Kontrol } & Statistic & df & Sig. & Statistic & df & Sig. \\
\cline { 3 - 8 } & & 0.201 & 25 & 0.10 & 0.904 & 25 & 0.23 \\
\hline
\end{tabular}

Berdasarkan hasil output analisis menunjukkan nilai Kolmogrov-Sminov dengan probabilitas (sig) sebesar 0,10 dan nilai Shapiro Wilk adalah dengan probabilitas sebesar 0,23. Oleh karena nilai probabilitas kedua nilai signifikan $>0,05$ maka ini berarti bahwa data hasil posttest kelompok kontrol berdistribusi normal yaitu tidak terdapat perbedaan frekuensi sebaran data kelompok kontrol.

\section{Hasil Pengujian Homogenitas Varians}

Tabel 3. Hasil Uji Homogenitas Varians dengan SPSS

\begin{tabular}{cccc}
\hline Levene Statistic & df1 & df2 & Signifikansi \\
\hline 1,801 & 1 & 47 & 0,186 \\
\hline
\end{tabular}

Berdasarkan hasil output analisis menunjukkan nilai sig. sebesar 0,186 . Oleh karena nilai signifikan $>0,05$, maka data hasil belajar kelompok eksperimen dan kelompok kontrol dikatakan homogen yaitu tidak terdapat perbedaan varians antara kelompok eksperimen dan kelompok control.

\section{Hasil Pengujian Hipotesis Penelitian}

Tabel 4. Hasil Uji Hipotesis dengan SPSS

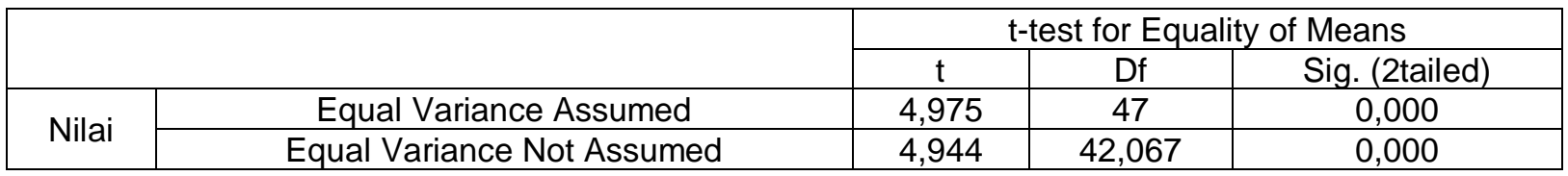

Berdasarkan hasil output analisis menunjukan nilai Sig. adalah 0,000 . Oleh karena nilai probabilitas siginifikan $<0,05$, maka $\mathrm{H} 0$ ditolak atau $\mathrm{H} 1$ diterima. Sehingga dapat dikatakan bahwa ada perbedaan hasil belajar antara siswa yang belajar menggunakan media virtual reality dengan siswa yang belajar menggunakan media kartu bergambar pada Materi pengenalan binatang buas di TK Wangun Sesana.

\section{Hasil Respon Siswa}

Data dari hasil respon anak terhadap penerapan media Virtual Reality pada tema pengenalan binatang buas, terhadap 24 anak kelompok eksperimen. Respon anak terhadap penerapan media Virtual Reality pada tema binatang dengan sub tema pengenalan binatang buas yang dikumpulkan dengan kuisioner atau angket tanggapan anak. Dari penyebaran angket respon yang disebarkan kepada anak pada akhir penelitian untuk mengetahui tanggapan atau respon anak terhadap penggunaan media Virtual Reality pada tema pengenalan binatang buas.

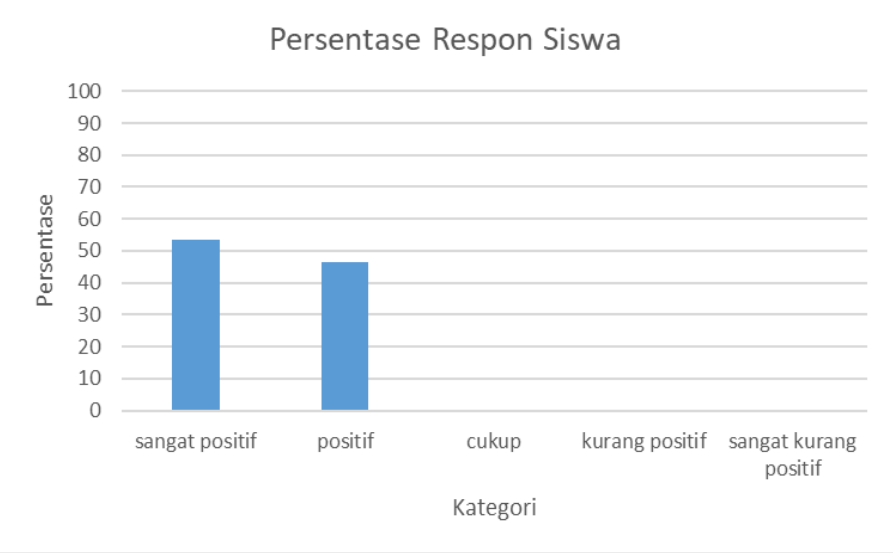

Gambar 6 Histogram Respon Siswa 
Diketahui bahwa respon siswa terhadap penggunaan Media Virtual Reality sebanyak $54,167 \%$ berkategori sangat positif, sebanyak $45.833 \%$ berkategori positif serta tidak ada respon siswa terhadap media Virtual Reality yang berkategori cukup, kurang positif dan sangat kurang positif.

\section{Pembahasan}

Pada bagian ini dibahas lebih lanjut mengenai hasil penelitian yang telah diperoleh. Sebelum menentukan sampel, terlebih dahulu menentukan anggota populasi. Populasi yang digunakan pada penelitian ini adalah seluruh anak kelompok B. total anak sebanyak 49 anak. Teknik pengambilan sampel dalam penelitian ini yaitu dengan cara simple random sampling. Hasil pengundian didapatkan bahwa kelompok B2 dengan jumlah 24 sebagai kelas eksperimen dan B1 dengan jumlah 25 adalah kelas kontrol. Hasil belajar pada kelompok eksperimen adalah 9,50 sedangkan rata-rata post-test pada hasil belajar kelompok kontrol sebesar 6,74. Dengan demikian, rata-rata post test hasil belajar pada kelompok eksperimen lebih besar dibandingkan kelompok kontrol. Perhitungan uji hipotesis dengan uji-t menggunakan Microsoft Excel 2010, dengan taraf signifikan 5\% dan derajat kebebasan 4 diperoleh thitung $=5,13795$ dan tabel $=1,67793$ Karena thitung $>$ tabel maka $\mathrm{H}_{0}$ ditolak dan $\mathrm{H}_{1}$ diterima. Sedangkan analisis uji-t dengan SPSS 16.0 mendapatkan hasil thitung $=4,975$ dan tabel dicari dengan tabel distribusi t pada taraf signifikan $5 \%$ satu sisi dan derajat kebebasan (df) adalah 47 , sehingga $t_{\text {tabel }}$ $=1,67793$ karena thitung $>$ tabel, maka $\mathrm{H}_{0}$ ditolak. Hal ini menunjukan bahwa bahwa terdapat hasil belajar yang lebih tinggi antara siswa yang belajar menggunakan media Virtual Reality dan siswa yang belajar menggunakan kartu bergambar pada kelompok B di TK Wangun Sesana. Selama pelaksanaan kegiatan pembelajaran, anak yang dibelajarkan dengan media pembelajaran Virtual Reality terlihat lebih aktif dalam pembelajaran dibandingkan dengan anak yang dibelajarkan dengan media pembelajaran kartu bergambar.

\section{SIMPULAN DAN SARAN}

\section{Simpulan}

Berdasarkan hasil penelitian dan pembahasan, dapat dikemukakan beberapa simpulan. Adapun simpulan yang akan dikemukakan dalam penelitian ini adalah sebagai berikut: (1) Terdapat hasil belajar yang lebih tinggi antara siswa yang belajar menggunakan media Virtual Reality dan siswa yang belajar menggunakan kartu bergambar, Dilihat rata-rata hasil belajar kelompok eksperimen dengan penerapan media Virtual Reality adalah 9,50 sedangkan rata-rata posttest untuk kelompok kontrol sebesar 6,74 maka dapat disimpulkan bahwa hasil belajar lebih tinggi terdapat pada anak yang yang menggunakan media Virtual Reality. (2) Hasil dari analisis respon siswa dari penerapan media Virtual Reality dilihat dari rata - rata skor respon siswa sebesar 4,54 adalah termasuk dalam kategori sangat positif.

\section{Saran}

Berdasarkan hasil penelitian dapat diajukan beberapa saran guna meningkatkan kualitas pembelajaran pada tema Binatang dengan subtema Pengenalan Binatang Buas. Hasil penelitian ini menunjukkan bahwa anak yang belajar dengan menggunakan media Virtual Reality memperoleh hasil belajar yang lebih baik daripada anak yang menggunakan media pembelajaran konvensional. Oleh karena itu, penulis menyarankan kepada guru pengajar untuk menerapkan media pembelajaran media Virtual Reality pada proses pembelajaran selanjutnya.

\section{UCAPAN TERIMAKASIH}

Dalam menyelesaikan penelitian ini, penulis banyak mendapat bantuan baik berupa moral maupun material dari berbagai pihak. Untuk itu pada kesempatan ini penulis berterimakasih kepada:

(1) Ida Shang Hyang Widhi Wasa yang selalu memberkati saya dalam menyusun penelitian ini.

(2) Dr. I Gede Sudirtha, S.Pd., M.Pd selaku Dekan Fakultas Teknik dan Kejuruan.

(3) I Made Agus Wirawan, S.Kom., M.Cs Selaku Ketua Jurusan Pendidikan Teknik Informatika.

(4) Nyoman Sugihartini, S.Pd., M.Pd. selaku pembimbing I yang telah membimbing dan memotivasi penulis dalam menyelesaikan penelitian ini.

(5) I Made Ardwi Pradnyana, S.T., M.T selaku pembimbing II yang telah membimbing dan memotivasi penulis dalam menyelesaikan penelitian ini.

(6) Kepala TK Wangun Sesana yang telah memberikan izin untuk melakukan penelitian di TK Wangun Sesana.

(7) Ibu guru pengajar di kelas Bermain. 
(8) Staf pegawai di TK Wangun Sesana yang selalu memberikan kelancaran dalam pencarian data untuk menyelesaikan peneitian ini.

(9) Anak-anak kelompok Bermain yang telah membatu dalam penelitian ini.

(10) I Made Sinda dan Ni Ketut Arini selaku orang tua penulis yang telah memberikan dorongan, semangat, doa serta bantuan baik moral maupun material.

(11) I Putu Pring Dana selaku kakak penulis yang selalu memberikan inspirasi dan penyemangat.

(12) Sahabat-sahabat sebagai tim sukses yang selalu bersedia saling membantu selama pengerjaan skripsi serta teman-teman PTI yang terlibat dalam pembuatan skripsi ini.

(13) Semua pihak yang tidak bisa disebutkan satu persatu yang telah membantu penyusunan penelitian ini

\section{DAFTAR PUSTAKA}

[1] Helmawati. (2015). Mengenal dan Memahami Paud. Bandung: PT Remaja Rosdakarya

[2] Bahar. (2014). Aplikasi Teknologi Virtual Reality Bagi Pelestarian Bangunan Arsitektur. Jurnal Desain Konstruksi.

[3] Pradnyana, I. A., Arthana, I. R., \& Sastrawan, I. B. (2017). Pengembangan Virtual Reality Pengenalan Binatang Buas Untuk Anak Usia Dini (Studi Kasus: TK Negeri Pembina Singaraja). LONTAR KOMPUTER VOL.8 No.3 Desember 2017.

[4] Lina. (2017). Pelaksanaan Model Pembelajaaran Klasikal Di TK Kecamatan Danau Kerinci. Fakultas Keguruan Dan IImu Pendidikan

[5] Miarso, Y. (2007). Menyemai Benih Teknologi Pendidikan Edisi 1 Cetakan 3. Jakarta: Kencana.

[6] Sugiyono. (2014). Metode Penelitian Pendidikan Pendekatan Kuantitatif, kualitatif dan R\&D. Bandung: Alfabeta.

[7] Ghozali, I. (2009). Aplikasi Analisis Multivariate dengan Program SPSS. Semarang: Universitas Diponegoro. 